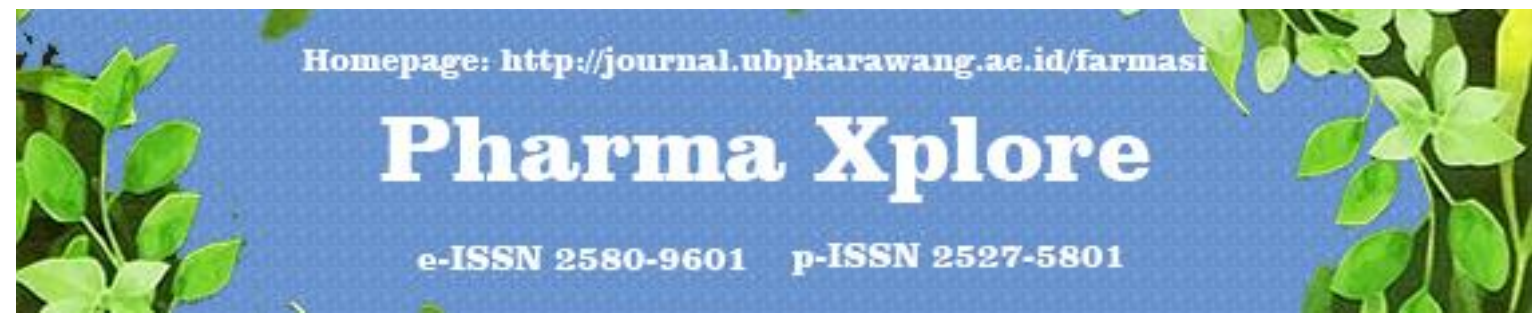

\title{
PENGARUH METODE EKSTRAKSI TERHADAP AKTIVITAS ANTIOKSIDAN DAN KADAR FLAVONOID DAUN KAREHO (Callicarpa Longifolia Lam)
}

\author{
Fadlilaturrahmah*, Nashrul Wathan, Akhmad Rezeki Firdaus, Saufy Arishandi \\ Universitas Lambung Mangkurat, Kota Banjarbaru, Kalimantan Selatan, Indonesia. \\ *Penulis korespondensi: fadlilaturrahmah@ulm.ac.id
}

\begin{abstract}
ABSTRAK
Tumbuhan Kareho (Callicarpa longifolia Lam. merupakan salah satu tanaman herbal yang mengandung senyawa flavonoid. Penelitian sebelumnya telah dilakukan untuk menilai kadar flavonoid tertinggi berdasarkan variasi pelarut, tetapi belum ada penelitian mengenai metode ekstraksi yang optimal untuk penentuan aktivitas antioksidan dan kadar flavonoid. Tujuan dari penelitian ini pada dasarnya adalah untuk mengevaluasi metode ekstraksi terbaik jika dilihat dari aktivitas antioksidan kadar flavonoid dan dari daun C.longifolia. Metode ekstraksi yang dilakukan dalam penelitian ini adalah maserasi, soxhlet dan perkolasi. Total kandungan flavonoid ditentukan dengan menggunakan metode aluminium klorida dan dihitung sebagai setara kuersetin (EK). Uji aktivitas antioksidan dilakukan secara in vitro dengan metode DPPH. Hasil menunjukkan bahwa semua ekstrak yang diperoleh dari metode ekstraksi yang berbeda menunjukkan antioksidan kuat, di mana aktivitas antioksidan tertinggi diperoleh dari metode ekstraksi perkolasi $\left(\mathrm{IC}_{50}=20,82 \mathrm{ppm}\right)$. Total kandungan flavonoid tertinggi diperoleh dari metode soxhlet $(12,37 \pm 0,03 \% \mathrm{~b} / \mathrm{b})$. Hasil penelitian menunjukkan bahwa perbedaan metode ekstraksi menghasilkan perbedaan yang signifikan (sig <0,05) pada aktivitas antioksidan dan kadar flavonoid dari daun C. longifolia.
\end{abstract}

Kata kunci : Callicarpa longifolia Lam, Ekstraksi, Antioksidan, Flavononid

\section{THE EFFECT OF EXTRACTION METHOD ON ANTIOXIDANT ACTIVITY AND FLAVONOID LEVELS OF KAREHO LEAVES (Callicarpa Longifolia Lam)}

\begin{abstract}
Kareho (Callicarpa longifolia) Lam. plants is one of the herbs contain flavonoid compounds. Previous research has been conducted to assess the highest levels of flavonoids based on solvent variations, but there has been no study examining the optimal extraction methods for determination of antioxidant activities and flavonoids content. The purpose of the research was essentially to evaluate the best technique for extraction flavonoid and antioxidant activities from C.longifolia leaves. Extraction method carried out in the study are maceration, soxhletation and percolation. Total flavonoid content determined using the aluminium chloride method and calculated as quercetin equivalents $(Q E)$. The antioxidant activity was performed following in vitro technique by DPPH assay. Results showed that all extracts obtained from different extraction methods exhibited a potent antioxidant, where the highest antioxidant activities was recorded for the percolation method extraction $\left(I C_{50}=20.82 \mathrm{ppm}\right)$. The highest of total flavonoid contents was recorded for the soxhletation method $(12.37 \pm 0.03 \% \mathrm{~b} / \mathrm{b})$. The result showed that the treatment effect of different extraction was significant (sig <0.05) on flavonoid total and antioxidant activities from $C$. longifolia.
\end{abstract}

Keywords: Callicarpa longifolia Lam., Extraction, Antioxidant, Flavonoid 


\section{PENDAHULUAN}

Indonesia merupakan negara kepulauan yang berada di daerah tropis dengan potensi tanaman obat terbesar kedua setelah Brazil. Sebanyak 40.000 spesies tumbuhan yang ditemukan dan tumbuh di seluruh dunia, 30.000 spesies di antaranya hidup di Indonesia (Salim dan Munadi, 2017). Sekitar 9.600 spesies tumbuhan berkhasiat sebagai obat dan 300 spesies telah digunakan sebagai bahan obat tradisional. Banyaknya ragam spesies tumbuhan tersebut menjadi suatu potensi bagi Indonesia sebagai produsen tanaman obat di dunia (Najib et al., 2017). Tumbuhan Callicarpa longifolia Lam. adalah salah satu tumbuhan yang mengandung senyawa flavonoid. Tumbuhan ini berasal dari famili Lamiaceae dan dikenal dengan nama Kareho. Tumbuhan ini dimanfaatkan sebagai pupur, obat masuk angin, dan bengkak oleh suku Dayak Tunjung Kaltim. Tumbuhan C. longifolia juga dimanfaatkan sebagai obat sakit perut dan diare pada bagian akarnya, sedangkan pada bagian daunnya digunakan sebagai bedak pembersih wajah dan obat malaria (Pasaribu et al, 2014; Setyowati, 2010). Penelitian sebelumnya menyebutkan bahwa fraksi etil asetat daun $C$. longifolia memiliki aktivitas antioksidan dengan nilai $\mathrm{IC}_{50}$ sebesar 38,94 ppm (Erwin dan Daniel, 2015). Berdasarkan penelitian lain menyebutkan bahwa telah dilakukan isolasi flavonoid dari fraksi etil asetat daun C. longifolia (Pasaribu et al., 2014; Novadiana et al., 2013).

Flavonoid merupakan suatu kelompok senyawa fenol terbanyak yang ditemukan di alam. Flavonoid termasuk dalam golongan senyawa fenolik. Berdasarkan hasil-hasil penelitian yang telah dilakukan sebelumnya, diyakini bahwa flavonoid adalah salah satu kelompok senyawa fenolik yang memiliki sifat antioksidatif serta berperan dalam mencegah kerusakan sel dan komponen selularnya oleh radikal bebas reaktif (Redha, 2010). Flavonoid diketahui juga dapat menunjukkan aktivitas biokimia misalnya antioksidan, anti virus, anti bakteri, dan anti kanker (Fowler et al., 2009). Penelitian ini menggunakan DPPH yang berperan sebagai radikal bebas yang akan diredam radikal bebasnya oleh sampel. Aktivitas peredaman radikal bebas oleh sampel biasanya disebutkan sebagai persen penghambatan atau persen inhibisi, dan dapat dinyatakan sebagai konsentrasi sampel yang menyebabkan hilangnya 50\% aktivitas DPPH (Yuhernita dan Juniarti, 2011). Hasil pengukuran dengan spektrofotometer cahaya tampak berupa data absorbansi digunakan untuk penentuan nilai persen penghambatan sampel terhadap DPPH. Nilai persen penghambatan dapat menunjukkan respon dari masing-masing konsentrasi uji (Daud et al., 2011). Penelitian ini menggunakan konsentrasi sampel sebesar 10 ppm. Berdasarkan penelitian Yuhernita dan 
Juniarti (2011) konsentrasi 10 ppm merupakan konsentrasi dimana terjadi penghambatan DPPH sebesar 50\% oleh asam askorbat yang sudah diketahui aktivitas antioksidannya.

Optimalisasi ekstraksi bertujuan mencari atau menemukan nilai perubah dalam proses yang menghasilkan nilai terbaik dari syarat-syarat kondisiiyang digunakan. Penyelesaian optimalisasi terfokus pada pemilihan secara tepat dan biaya yang hemat diantara keseluruhan dan proses metode kuantitatif yang efisien (Febrina et al., 2015). Flavonoid diketahui merupakan senyawaayang bersifat stabil terhadap pemanasan dengan suhu tertentu. Meningkatnya suhuumenyebabkan peningkatan kadar flavonoid sampai pada suhu tertentu kemudian menurun seiring dengan peningkatan suhu yang lebih tinggi (Riadini et al., 2015).

Penelitian sebelumnya telah dilakukan untuk menentukan pelarut yang paling optimal dari etanol 70\%, etanol 96\% dan metanol berdasarkan parameter kadar flavonoid total ekstrak daun $C$. longifolia. Pelarut yang menghasilkan kadar flavonoid tertinggi pada daun $C$. longifolia adalah pelarut metanol (Maulida, 2018). Berdasarkan hal yang telah diuraikan di atas maka dilakukan penelitian pengaruh metode ekstraksi terhadap aktivititas antioksidan dan kadar flavonoid kareho (Calicarfa longifolia L).

\section{BAHAN DAN METODE}

\section{Alat dan Bahan}

Alat-alat yang digunakan pada penelitian kali ini adalah alat gelas, maserator, seperangkat alat sokhlet, perkolator, neraca analitik (Ohauss), plat KLT, vortex, spektrofotometer UV-Vis (Spectronic Genesys $10 \mathrm{uv}$ ), waterbath (SMIC) dan rotary evaporator (Heidolph).

Bahan yang digunakan dalam penelitian ini adalah daun C. longifolia, aquadest, natrium hidroksida $10 \%$, aluminium foil, kertas saring, metanol p.a, etanol p.a, metanol teknis, aluminium klorida 10\%, standar kuersetin (Sigma), etil asetat p.a, n-heksan p.a, aquadest, asam asetat $5 \%$ dan pereaksi DPPH.

\section{Preparasi Sampel dan Ekstraksi Daun C. longifolia}

Tumbuhan yang digunakan pada penelitian ini adalah daun C. longifolia segar yang diambil pada bulan Februari 2019 di Kelurahan Beriwit, Kecamatan Murung, Kabupaten Murung Raya, Provinsi Kalimantan Tengah. Preparasi sampel dilakukan dengan sortasi basah, pencucian, pengeringan, sortasi kering. Pengolahan serbuk dilakukan dengan 
menggunakan blender hingga menjadi serbuk (Puspitasari \& Proyogo, 2017). Serbuk simplisia daun $C$. longifolia ditimbang sebanyak 20 gram yang masing-masing digunakan untuk ekstraksi dengan metode yang berbeda yaitu maserasi, soxhlet, dan perkolasi. Filtrat hasil ekstraksi diuapkan dengan rotary evaporator kemudian dipekatkan di waterbath hingga diperoleh ekstrak kental. Ekstrak ditimbang dan dihitung persentase rendemennya.

\section{Penetapan kadar flavonoid dengan menggunakan spektrofotometri UV-Vis Pembuatan kurva baku standar}

Sebanyak 10 mg kuarsetin ditimbang dan dimasukan ke dalam labu ukur $10 \mathrm{~mL}$. Lalu ditambahkan etanol p.a sampai tanda batas. Dari larutan induk kuarsetin diambil 0,4;0,6; 0,$8 ; 1,0 ; 1,2 \mathrm{~mL}$ dan masing-masing dimasukkan ke dalam labu ukur $10 \mathrm{~mL}$ lalu ditambahkan etanol p.a sampai tanda batas. Larutan standar dengan konsentrasi 40; 60; 80; 100 dan 120 ppm tersebut lalu diambil 0,5 mL kemudian dimasukkan ke dalam tabung reaksi. Larutan tersebut lalu ditambahkan dengan $0,1 \mathrm{~mL} \mathrm{AlCl}_{3} 10 \%, 0,1 \mathrm{~mL}$ asam asetat $5 \%$ dan 2,8 $\mathrm{mL}$ aquades kemudian didiamkan pada suhu ruang selama operating time (28 menit) dan diukur pada panjang gelombang maksimum (416nm). Dilakukan replikasi sebanyak 3 kali.

\section{Penetapan Kadar Flavonoid}

Penetapan kadar flavonoid ekstrak metanol daun C. longifolia dari 3 metode yaitu maserasi, soxhlet, dan perkolasi masing-masing dibuat pada konsentrasi sebesar 1000 ppm, dengan menimbang $10 \mathrm{mg}$ ekstrak dan dilarutkan dengan etanol p.a dalam labu ukur $10 \mathrm{~mL}$ sampai tanda batas. Sebanyak 0,5 $\mathrm{mL}$ larutan tersebut diambil lalu masing-masing ditambahkan dengan 1,5 mL etanol p.a kemudian direaksikan dengan $0,1 \mathrm{~mL} \mathrm{AlCl}_{3}$ 10\%, $0,1 \mathrm{~mL}$ asam asetat $5 \%$ dan $2,8 \mathrm{~mL}$ aquadest. Larutan dikocok dan didiamkan selama operating time (28 menit). Lalu dilakukan replikasi sebanyak 3 kali. Absorbansi larutan dibaca pada panjang gelombang maksimum (416nm). Blanko yang digunakan yaitu etanol p.a yang direaksikan dengan $\mathrm{AlCl}_{3} 10 \%$, asam asetat $5 \%$ dan aquadest.

\section{Penentuan aktivitas antioksidan ekstrak metanol daun $C$. longifolia}

Sebanyak $10 \mathrm{mg}$ sampel dari ekstrak metode maserasi (CLM), soxhlet (CLS) dan perkolasi (CLP) masing-masing dilarutkan dalam $10 \mathrm{~mL}$ metanol p.a. Kemudian larutan tersebut dibuat dengan konsentrasi 100 ppm dengan mengambil sebanyak $1 \mathrm{~mL}$, selanjutnya dimasukkan ke dalam labu ukur $10 \mathrm{~mL}$ dan ditambah dengan metanol p.a hingga tanda batas. 
Kemudian dibuat larutan dengan konsentrasi 10 ppm dengan diambil masing-masing konsentrasi sampel sebanyak $1 \mathrm{~mL}$ dan di masukkan ke dalam labu ukur $10 \mathrm{~mL}$ dan ditambah metanol p.a hingga tanda batas. Larutan tersebut masing-masing diambil sebanyak $4 \mathrm{~mL}$ dan dimasukkan ke dalam tabung reaksi. Kemudian sebanyak $1 \mathrm{~mL}$ larutan DPPH 0,4 mMol ditambahkan. Kemudian dilakukan pembacaan absorbansi menggunakan spektrofotometer UV-Vis direntang panjang gelombang maksimum (516nm). Dilakukan replikasi sebanyak 3 kali. Nilai IC $_{50}$ merupakan konsentrasi dimana sampel dapar menghambat radikal bebas sebesar 50\% yang diperoleh dengan memakai persamaan regresi linear $\mathrm{y}=\mathrm{bx}+\mathrm{a}$.

$$
\% \text { inhibisi }=\frac{\text { Absorbansi Blanko-Absorbansi Sampel }}{\text { Absorbansi Blanko }} \times 100 \%
$$

\section{HASIL DAN PEMBAHASAN}

\section{Preparasi Sampel dan Ekstraksi Daun C. longifolia}

Sampel daun segar yang digunakan pada penelitian ini sebanyak $2 \mathrm{~kg}$. Bagian tumbuhan yang dijadikan sampel adalah daun dari tumbuhan kareho (Callicarpa longifolia Lam.) yang diambil pada bulan Februari di Kelurahan Beriwit, Kecamatan Murung, Kabupaten Murung Raya, Provinsi Kalimantan Tengah. Pembuatan serbuk simplisia daun C. longifolia diawali dengan sortasi basah. Sortasi basah bertujuan untuk memisahkan daun yang rusak, kotoran, dan benda asing setelah proses pengambilan sampel di lapangan. Proses pengeringan menggunakan oven bertujuan untuk mengurangi kandungan air, sehingga dapat menghambat pertumbuhan mikroba Selain itu untuk mencegah tumbuhnya kapang dan jamur sehingga diperoleh simplisia yang awet dan dapat disimpan dalam jangka waktu yang lama. Proses sortasi kering kemudian dilakukan untuk memisahkan sampel yang telah rusak akibat proses sebelumnya. Proses penghalusan sampel dilakukan dengan menggunakan blender hingga didapat serbuk yang kasar agar proses ekstraksi dapat berjalan dengan baik.

Metode yang digunakan dalam penelitian ini adalah ekstraksi dengan cara dingin dengan metode maserasi dan perkolasi serta cara panas dengan soxhlet. Pada proses maserasi dilakukan proses pengadukan bertujuan agar terjadinya kesetimbangan konsentrasi bahan yang diekstraksi lebih cepat didalam cairan penyari. Pada proses ini,setiap 24 jam pelarut diganti dengan pelarut yang baru yang bertujuan untuk mencegah terjadinya penjenuhan pelarut sehingga senyawa yang tertarik pada saat ekstraksi lebih maksimal (Mukhriani, 2014). Metode ekstraksi dengan soxhlet dilakukan sebanyak 15 siklus untuk 
mendapatkan parameter berupa ekstrak yang bening pelarutnya. Suhu yang digunakan dalam proses ini adalah $64^{\circ} \mathrm{C}$ karena merupakan titik didih dari pelarut yang digunakan yaitu metanol. Diketahui senyawa flavonoid dapat stabil pada suhu $70^{\circ} \mathrm{C}$ sehingga suhu pada proses ini terus dijaga hingga tidak melebihi $70^{\circ} \mathrm{C}$ karena suhu yang terlalu tinggi dapat merusakksenyawa flavonoid (Puspitasari dan Proyogo, 2017).

Metode ekstraksi dengan perkolasi dilakukan dengan proses perendaman terhadap serbuk simplisia agar rongga simplisia membengkak sehingga mempermudah pelarut masuk ke dalam sel. Hasil dari rata-rata persen rendemen ekstrak CLM, CLS, dan CLP berturutturut sebesar $14,35 \pm 0,726 \%, 17,5 \pm 0,35 \%$ dan $15 \pm 1,153 \%$. Persen rendemen daun $C$. longifolia paling besar dihasilkan pada metode soxhlet dibandingkan dengan metode maserasi dan perkolasi. Berdasarkan penelitian Mukhriani (2014) kelebihan dari metode soxhlet adalah proses ekstraksi yang kontinyu dan sampel terekstraksi oleh pelarut murni hasil kondensasi sehingga rendemen yang dihasilkan lebih banyak. Pemanasan dapat meningkatkan kemampuan untuk mengekstraksi senyawa-senyawa yang tidak laruttdalam suhu kamar, sehingga aktivitas penarikan senyawa lebih maksimal.

Analisis Kualitatif Daun C. longifolia

Identifikasi golongan senyawa dapat dilakukan dengan metode kromatografi lapis tipis berdasarkan nilai Rf (Mukhriani, 2014). Pengujian dilakukan dengan cara menguapkan plat KLT yang sudah ditotolkan dan dielusi di atas uap ammonia. Bercak noda berwarna kuning pada plat KLT menunjukkan hasil positif mengandung flavonoid (Nuari, 2017).
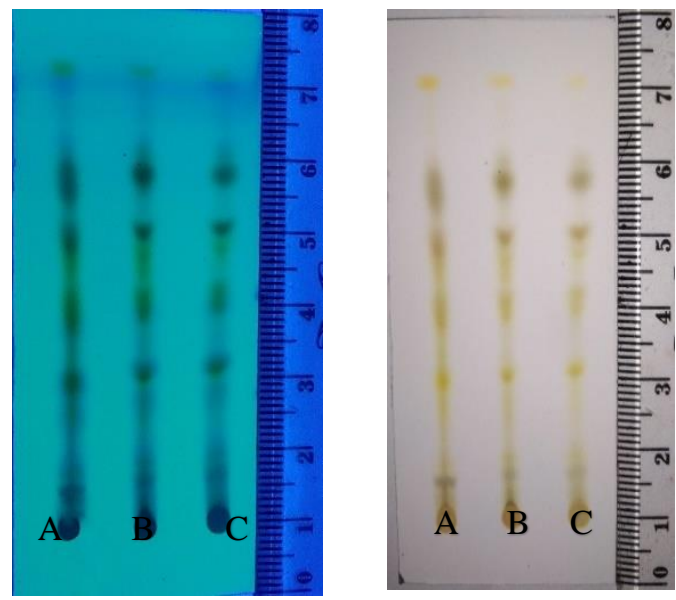

Gambar 1. Hasil KLT fase gerak n-heksan - etil asetat (7:3) pada lampu uv 254 dan setelah ditambah pereaksi uap ammonia. Keterangan : A. CLP; B. CLS; C. CLM. 
Noda yang berwarna kuning pada plat yaitu pada maserasi dengan nilai Rf 0,32 dan 0,46, soxhlet dengan nilai Rf 0,30 dan 0,46 dan perkolasi dengan nilai Rf 0,29 dan 0,44. Disimpulkan ada kemungkinan terkandung senyawa flavonoid berdasarkan bercak noda berwarna kuning tersebut. Hal ini sesuai dengan penelitian Rahayu et al (2015) dengan menggunakan perbandingan fase gerak n-heksan-etil asetat (6:4) menyebutkan noda dengan nilai Rf antara 0,2-0,75 menunjukkan noda yang mengandung flavonoid. Penetapan kadar flavonoid total dilakukan menggunakan 3 jenis metode ekstraksi yaitu maserasi, soxhlet, dan perkolasi daun $C$. longifolia. Nilai absorbansi dari masing-masing ekstrak dimasukkan dalam persamaan kurva baku kuersetin yang telah didapat sebelumnya yaitu $y=0,003 x-$ 0,0052 .

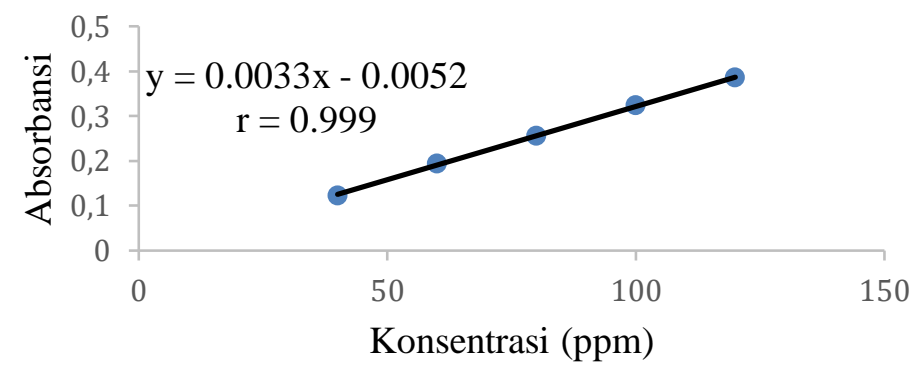

Gambar 2. Grafik kurva baku kuersetin

Berdasarkan grafik di atas, diperoleh persamaan regresi yaitu $y=0,003 x-0,0052$. Nilai linieritas (r) yang diperoleh adalah 0,999. Keakuratan yang didapatkan 99,9\% dengan tingkat kesalahan yang terjadi hanya $0,1 \%$. Linieritas menyatakan adanya hubungan yang linier antara konsentrasi dan absorbansi larutan seri kadar yang didapat. Semakin mendekati 1 maka hasil yang didapatkan semakin linier. Hal ini telah sesuai dengan literatur yang menyatakan liniearitas baik apabila nilai koefesien korelasi (r) mendekati 1. Hasil analisis Post Hoct Test menunjukkan bahwa antara metode maserasi dengan soxhlet, maserasi dengan perkolasi ataupun soxhlet dengan perkolasi terdapat perbedaan yang bermakna terhadap kadar flavonoid total yang ditandai dengan nilai (sig $<0,05)$. Berdasarkan hasil perhitungan kadar flavonoid total di atas didapat metode yang paling optimal menarik senyawa flavonoid adalah metode soxhlet. 
Tabel 1. Hasil perhitungan kadar flavonoid total

\begin{tabular}{|c|c|c|c|c|}
\hline $\begin{array}{l}\text { Metode } \\
\text { Ekstraksi }\end{array}$ & $\begin{array}{l}\text { RSD } \\
(\%)\end{array}$ & $\begin{array}{l}\text { Kadar flavonoid } \\
\text { total (\%b/b EK) }\end{array}$ & $\begin{array}{l}\text { Rata-rata Kadar flavonoid } \\
\text { total }(\% \mathrm{~b} / \mathrm{b} \text { EK }) \pm \text { SD }\end{array}$ & $\begin{array}{l}\text { RSD } \\
(\%)\end{array}$ \\
\hline Maserasi & 0,650 & $\begin{array}{c}8,04 \\
8 \\
7,94\end{array}$ & $7,995 \pm 0,050$ & 0,635 \\
\hline Soxhlet & 0,273 & $\begin{array}{c}12,34 \\
12,37 \\
12,4\end{array}$ & $12,37 \pm 0,03$ & 0,242 \\
\hline Perkolasi & 0,948 & $\begin{array}{c}9,106 \\
9,006 \\
8,94\end{array}$ & $9,017 \pm 0,083$ & 0,926 \\
\hline
\end{tabular}

Flavonoid yang terdapat dalam daun C. longifolia stabil terhadap pemanasan. Berubahnya suhu selama proses ekstraksi mempengaruhi kelarutan suatu senyawa karena adanya pengaruh massa jenis (massa jenis sangat sensitif terhadap perubahan suhu), semakin tinggi suhu pada proses ekstraksi maka dapat mempercepat perpindahan massa dan meningkatkan hasil ekstraksi. Pada metode maserasi dan perkolasi tidak ada pemanasan sehingga hasil ekstraksi juga tidak meningkat. Penelitian yang dilakukan oleh Puspitasari dan Proyogo (2017) kadar flavonoid total tertinggi daun kersen (Muntingia calabura) dihasilkan pada ekstrak etanol metode soxhlet dibanding dengan ekstrak etanol metode maserasi. Berdasarkan penelitian Verawati et al (2016) nilai kadar fenol total tertinggi ekstrak daun piladang (Solenostemon scutellarioides (L.) Codd) yang juga tergolong dalam family Lamiaceae sama seperti sampel penelitian ini yaitu daun $C$. longifolia terdapat pada metode soxhlet. 
Tabel 2. Hasil perhitungan aktivitas antioksidan

\begin{tabular}{cccc}
\hline $\begin{array}{c}\text { Metode } \\
\text { Ekstraksi }\end{array}$ & $\begin{array}{c}\text { Konsentrasi } \\
(\mathrm{ppm})\end{array}$ & Inhibisi $(\%)$ & $\begin{array}{c}\mathrm{IC}_{50} \\
(\mathrm{ppm})\end{array}$ \\
\hline Maserasi & 10 & 33,26 & \\
& 15 & 36.32 & 35,39 \\
& 20 & 39,99 & \\
& 25 & 44,08 & \\
Perkolasi & 30 & 45,72 & \\
& 10 & 32,09 & \\
& 15 & 45,28 & \\
& 20 & 49,79 & \\
& 25 & 51,30 & \\
& 30 & 64,95 & \\
& 10 & 39,39 & \\
& 15 & 39,58 & \\
& 20 & 45,72 & \\
& 25 & 48,89 & \\
\hline Kuersetin & 30 & 51,97 & \\
& 2 & 21,5 & \\
& 3 & 28,34 & \\
& 4 & 36,01 & \\
& 5 & 45,12 & \\
& 6 & 52,24 & \\
\hline
\end{tabular}

Nilai aktivitas antioksidan yang paling aktif pada penelitian ini adalah metode perkolasi karena memiliki nilai $\mathrm{IC}_{50}$ paling rendah dibandingkan dibandingkan metode maserasi dan soxhlet. Aktivitas antioksidan ini tidak lepas dari peranan senyawa metabolit sekunder golongan flavonoid. Nilai flavonoid tertinggi pada penelitian ini didapat dari soxhlet, tetapi pada aktivitas antioksidan soxhlet lebih rendah dibandingkan dengan perkolasi. Menurut penelitian Jing et al., (2015) peningkatan suhu dapat mengakibatkan pergerakan molekular yang mempercepat disolusi sehingga meningkatkan kadar flavonoid. Namun, peningkatan suhu yang terlalu tinggi akan menyebabkan denaturasi antioksidan termo-sensitif yang mungkin lebih stabil pada suhu yang lebih rendah. Oleh karena itu kadar flavonoid tertinggi pada metode soxhlet tidak memiliki aktivitas penghambat radikal bebas yang tinggi. Suhu yang direkomendasikan untuk menghindari denaturasi antioksidan termosensitif adalah $60^{\circ} \mathrm{C}$. Berdasarkan hal tersebut dapat disimpulkan bahwa kadar flavonoid total tidak berbanding lurus dengan aktivitas antioksidan. Selain itu juga bisa disebabkan kandungan kimia yang berefek terhadap antioksidan tidak hanya flavonoid, bisa juga dipengaruhi oleh kandungan senyawa fitokimia lainnya seperti golongan fenolik ataupun tanin. 


\section{KESIMPULAN}

Kadar flavonoid ekstrak metanol daun C. longifolia dengan metode maserasi sebesar 7,995 $\pm 0,050 \% \mathrm{~b} / \mathrm{b}$ EK, soxhlet sebesar 12,37 $\pm 0,03 \% \mathrm{~b} / \mathrm{b}$ EK dan perkolasi sebesar 9,017 $\pm 0,083 \% \mathrm{~b} / \mathrm{b}$ EK. Metode ekstraksi yang paling optimal untuk menghasilkan kadar flavonoid total tertinggi dari ekstrak metanol daun $C$. longifolia adalah metode soxhlet. Aktivitas antioksidan yang paling aktif diperoleh dari ekstrak metanol metode perkolasi dengan nilai $\mathrm{IC}_{50}$ sebesar 20,82 ppm

\section{UCAPAN TERIMAKASIH}

Penelitian ini dapat terlaksana karena dana DIPA PNBP FMIPA Universitas Lambung Mangkurat.

\section{DAFTAR PUSTAKA}

Daud, M.F., Sadiyah, E.R., Rismawati, E. Pengaruh Perbedaan Metode Ekstraksi Terhadap Aktivitas Ekstrak Etanol Daun Jambu Biji (Psidium guajava L.) Berdaging Buah Putih. Prossiding Seminar Nasional dan PKM Sains, Teknologi, dan Kesehatan. 2011; 2: 55-6.

Erwin, R.A. Nisa and Daniel. Phytochemical Test, Tokxicity and Antioxidant Activity Leaves Sangkareho (Callicarpa longifolia Lam.) With DPPH Method. Indonesia Chimica Acta. 2015; 8: 52-59.

Febrina, L., Rusli, R., Muflihah F. Optimalisasi Ekstraksi Dan Uji Metabolit Sekunder Tumbuhan Libo (Ficus Variegate Blume). J. Trop. Pharm. Chem. 2015; 3: 74-81.

Fowler, L.Z., Mattheos, A., Koffas. Biosynthesis and biotechnological production of flavanones: current state and perspectives. Appl Microbiol Biotechnol. 2009; 83: 799808.

Jing, C.L., Dong, X.F., Tong, J.M. Optimization of Ultrasonic-Assisted Extraction of Flavonoid Compounds and Antioxidants from Alfalfa Using Response Surface Method. Molecules. 2015; 20: 15550-15571.

Maulida, S.M. Penetapan Kadar Flavonoid Total dari Ekstrak Etanol 70\%, Etanol 96\% dan Metanol Daun Kareho (Callicarpa longifolia Lam.). Skripsi. Program Studi Farmasi, Universitas Lambung Mangkurat, Banjarbaru. 2018.

Mukhriani. Ekstraksi, Pemisahan Senyawa, dan Identifikasi Senyawa Aktif. Jurnal Kesehatan. 2014; 7: 361-367.

Mulyani, S. dan Laksana, T. Analisis Flavonoid dan Tannin Dengan Metoda Mikroskopimikrokimiawi. Majalah Obat Tradisional. 2011; 16: 109-114. 
Najib, A., Malik, A., Ahmad, A.R., Handayani, V., Syarif, R.A., Waris, R. Standarisasi Ekstrak Air Daun Jati Belanda dan Teh Hijau. Jurnal Fitofarmaka Indonesia. 2017; 2: 241-245.

Novadiana, A., Erwin, Pasaribu, S.P. Uji Toksisitas (Brine Shrimp Lethality Test) Ekstrak dan Isolat Fraksi Kloroform dari daun Karehau (Callicarpa longifolia Lamk.). Prosiding Seminar Nasional Kimia Kalimantan Timur. 2013. Hal. 134 -140.

Nuari, S., Anam, S., Khumaidi, A. Isolasi dan Identifikasi Senyawa Flavonoid Ekstrak Etanol Buah Naga Merah (Hylocereus polyrhizus (F.A.C Weber) Briton dan Rose. Jurnal Farmasi Galenika. 2017; 2: 118-125.

Pasaribu, S.P., Erwin, Istianti, P. Isolasi dan Identifikasi Senyawa Flavonoid dari Daun Tumbuhan Sangkareho (Callicarpa longifolia Lam.). Jurnal Kimia Mulawarman. 2014; 11: 80-83.

Puspitasari, A.D., dan Proyogo, L.S. Perbandingan Metode Ekstraksi Maserasi dan Sokhletasi Terhadap Kadar Flavonoid Total Ekstrak Etanol Daun Kersen (Muntingia calabura). Program studi S1 Farmasi Fakultas Farmasi Universitas Wahid Hasyim Semarang. 2017; 2: 16-23.

Rahayu, S., Kurniasih, N., Amalia, V. 2015. Ekstraksi dan Identifikasi Senyawa Flavonoid dari Limbah Kulit Bawang Merah Sebagai Antioksidan Alami. Al kimiya. 2015; 2: 18.

Redha, A. 2010. Flavonoid: Struktur, Sifat Antioksidatif dan Peranannya dalam Sistem Biologis. Jurnal Belian. 2010; 9: 196-202.

Riadini, R.K., Sidharta, B.B.R., Pranata, F.S. Uji Aktivitas Antioksidan Ekstrak Daun Sambung Nyawa (Gynurapro cumbens (Lour.) Merr) Berdasarkan Perbedaan Metode Ekstraksi dan Umur Panen. e-journal. 2015. Hal: 11.

Salim, Z. dan Munadi, E. Info Komoditi Tanaman Obat. Kementrian Perdagangan Republik Indonesia, Jakarta. 2017.

Setyowati, F.M. Artikel Etnofarmakologi dan Pemakaian Tanaman Obat Suku Dayak Tunjung Kalimantan Timur. Media Litbang Kesehatan 2010; 20 (3).

Simaremare, E.S. Skrining Fitokimia Ekstrak Etanol Daun Gatal (Laportea decumana (Roxb.) Wedd). Pharmacy. 2014; 11. 98-107.

Yuhernita dan Juniarti. Analisis Senyawa Metabolit Sekunder Dari Ekstrak Metanol Daun Surian Yang Berpotensi Sebagai Antioksidan. Makara, Sains. 2011; 15: 48-52. 